\title{
Morphological and physiological changes in Saccharomyces cerevisiae by oxidative stress from hyperbaric air
}

\author{
I. Belo*, R. Pinheiro, M. Mota \\ Centro de Engenharia Biológica, Universidade do Minho, Campus de Gualtar, 4710-057 Braga, Portugal
}

Received 25 February 2004; received in revised form 20 September 2004; accepted 27 September 2004

\begin{abstract}
Increase in air or oxygen pressure in microbial cell cultures can cause oxidative stress and consequently affect cell physiology and morphology. The behaviour of Saccharomyces cerevisiae grown under hyperbaric atmospheres of air and pure oxygen was studied. A limit of 1.0 MPa for the air pressure increase (i.e. 0.21 MPa of oxygen partial pressure) in a fed-batch culture of $S$. cerevisiae was established. Values of 1.5 MPa air pressure and $0.32 \mathrm{MPa}$ pure oxygen pressure strongly inhibited the metabolic activity and the viability of the cells. Also, morphological changes were observed, especially cell-size distribution and the genealogical age profile. Pressure caused cell compression and an increase in number of aged cells. These effects were attributed to oxygen toxicity since similar results were obtained using air or oxygen, if oxygen partial pressure was equal to or higher than 0.32 MPa. The activity of the antioxidant enzymes, catalase and superoxide dismutase (SOD) (cytosolic and mitochondrial isoformes) indicated that the enzymes have different roles in oxidative stress cell protection, depending on other factors that affect the cell physiological state.
\end{abstract}

(C) 2004 Elsevier B.V. All rights reserved.

Keywords: Air pressure; Oxidative stress; Saccharomyces cerevisiae; Morphology

\section{Introduction}

Many enzymes, antibiotics, biochemicals, diagnostics and therapeutics are produced using aerated bioreactors. Supplying oxygen to aerobic cells has always represented a significant challenge to fermentation technologists due to the low oxygen solubility in cul-

\footnotetext{
* Corresponding author. Tel.: +351 253604400 ; fax: +351253678986 .

E-mail address: ibelo@deb.uminho.pt (I. Belo).
}

ture media. In order to overcome this problem, air pressure increases have been proposed by many authors (Yang and Wang, 1992; Wendlandt et al., 1993; Belo and Mota, 1998; Pinheiro et al., 2000).

Total air pressure is an important operating factor because it affects local dissolved oxygen tension, and may influence cell morphology and physiology.

Despite the fact that oxygen is an essential nutrient for aerobic organisms, it can also be a toxic agent that can damage cells by the action of reactive oxygen 
species (ROS). ROS are by-products of the normal cellular metabolism but generation is stimulated by many different stress conditions, including oxygen pressure increase (Moradas-Ferreira et al., 1996). However, aerobic cells have evolved several defence mechanisms. Antioxidant enzymes, such as catalase and superoxide dismutase (SOD), constitute the primary defences of the cells because they are responsible for the degradation of some ROS. Oxidative stress is a well-known phenomenon that results whenever the ROS concentrations exceed the antioxidant capacity of the cells (Santoro and Thiele, 1997). The cellular damage caused by oxidative stress is due to the chain reactions that are established between the ROS and the biomolecules of the cells, such as DNA, proteins and lipids. Thus, oxidative stress affects cellular physiology and morphology. The present report investigates the effects of increased air and oxygen pressure on the oxidative stress response of Saccharomyces cerevisiae in a fed-batch bioreactor. This is the most used mode of cultivation for the production of yeast biomass used in many important industrial processes, such as baker's yeast (Van Hoek et al., 2000) and recombinant proteins production (Koo et al., 1998). Cellular behaviour under different air and oxygen pressures was followed by the analysis of several aspects: metabolic activity of the cells, cellular viability, intracellular antioxidant enzymes activity, genealogical profile of the cells and cell-size distribution. Cell size was evaluated by computer-aided image analysis techniques. This methodology has been proven to be very accurate and rapid, and it has been applied for decades in the measurement of cell viability by epi-fluorescence (Raynal et al., 1994), in the assessment of the physiological state of cells by the measurement of vacuoles size (Zalewski and Buchholz, 1996) and of cell volume (Gervais et al., 1992).

\section{Materials and methods}

\subsection{Yeast strain and medium}

S. cerevisiae ATCC 32167 was used in this study and was preserved at $-80{ }^{\circ} \mathrm{C}$ in $20 \%(\mathrm{v} / \mathrm{v})$ glycerol. Agar plates $\left(20 \mathrm{~g} \mathrm{~L}^{-1}\right.$ agar) were inoculated from stock cultures and cells were grown by incubation overnight at $30{ }^{\circ} \mathrm{C}$. The culture medium consisted of $5 \mathrm{~g} \mathrm{KH}_{2} \mathrm{PO}_{4}$,

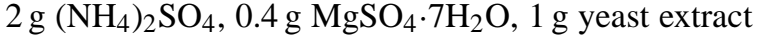
(DIFCO), $5 \mathrm{~g}$ glucose and $1 \mathrm{~L}$ of distilled water. The $\mathrm{pH}$ was adjusted to 4.0 prior to autoclaving. Colonies from an agar plate were grown in $200 \mathrm{~mL}$ of culture medium, at $150 \mathrm{rpm}$ and $30^{\circ} \mathrm{C}$, for $16 \mathrm{~h}$. Cells from this pre-culture were harvested by centrifugation, resuspended in $130 \mathrm{~mL}$ of fresh medium and fed into the bioreactor.

\subsection{Fed-batch cultivation}

Fed-batch experiments were carried out in a $600 \mathrm{~mL}$ stainless steel bioreactor (Parr 4563) at a temperature of $30^{\circ} \mathrm{C}$, stirring rate of $400 \mathrm{rpm}$ and a gas flow rate of $1 \mathrm{~L} \mathrm{~min}^{-1}$ (measured at $0{ }^{\circ} \mathrm{C}$ and $0.1 \mathrm{MPa}$ ). The operating pressure was set by compressed gas pressure (inlet gas) and the regulatory valve position in the exit gas line.

The medium was similar to that used in inoculum preparation, with the exception that $2 \mathrm{gL}^{-1}$ glucose and $1 \mathrm{~mL}$ of antifoam (Merck 7743) were used. The feed medium contained per litre: $7.5 \mathrm{~g} \mathrm{KH}_{2} \mathrm{PO}_{4} \mathrm{~L}^{-1}$,

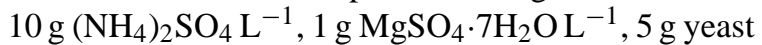
extract $\mathrm{L}^{-1}$ and $60 \mathrm{~g}$ glucose $\mathrm{L}^{-1}$.

An exponentially feeding profile was used according with Eq. (1) (Yee and Blanch, 1992).

$F(t)=\frac{\mu X_{\mathrm{o}} V_{\mathrm{o}} \exp (\mu t)}{S_{\mathrm{F}} Y_{\mathrm{X} / \mathrm{S}}}$

where $X_{\mathrm{o}}$ is the initial cell concentration in the fedbatch phase $\left(3 \mathrm{gL}^{-1}\right)$ and $V_{\mathrm{o}}$ is the culture volume when the medium feed started $(130 \mathrm{~mL})$. The other variables assumed the following values: $S_{\mathrm{F}}=60 \mathrm{~g} \mathrm{~L}^{-1}$, $Y_{\mathrm{X} / \mathrm{S}}=0.5 \mathrm{~g} \mathrm{~g}^{-1}$ (grams of cell dry weight per gram of glucose) and $\mu=0.1 \mathrm{~h}^{-1}$. The medium was pumped into the reactor using a high-pressure pump (Jasco 880PU) with flow rates between $1 \mathrm{~mL} \mathrm{~h}^{-1}$ and $25 \mathrm{~mL} \mathrm{~h}^{-1}$ according with Eq. (1). The pump automatically performed the flow rate increment. In the pump programme, the exponential function was approximated by a sequence of several linear functions of increasing slopes.

A constant specific glucose uptake rate of $0.2 \mathrm{~g} \mathrm{~g}^{-1} \mathrm{~h}^{-1}$ was expected for the feeding flow profile used, assuming the cells followed a oxidative metabolism. The same feed flow rates were used for all the experiments. 


\subsection{Analytical procedures}

Cell concentration ( $\mathrm{gL}^{-1}$ dry weight) was obtained by measuring the absorbance of the suspension at $620 \mathrm{~nm}$ using a previously determined correlation. Glucose concentration was measured by the 3,5dinitrosalycilic acid method (Miller, 1959). Ethanol was quantified by gas chromatography (column CPWAX 57 CB, Chrompack). Catalase and SOD activities were assayed in cell extracts by the method of Beers and Sizer (1952) and the method of McCord and Fridovich (1969), respectively. To distinguish mitochondrial SOD (MnSOD) from cytosolic SOD (CuZnSOD) the same method was applied but in the presence of $0.6 \mathrm{M} \mathrm{KCN}$ to inhibit the cytosolic isoform. Activities were expressed as units of enzymatic activity per milligram of total soluble protein $\left(\mathrm{U} \mathrm{mg}^{-1}\right)$, which was assayed by method of Bradford (1976). Cells were harvested by centrifugation $(5000 \times \mathrm{g}, 10 \mathrm{~min}$, $4{ }^{\circ} \mathrm{C}$ ) for the cell extracts preparation. The cell pellets were washed once with $50 \mathrm{mM}$ potassium phosphate buffer $\mathrm{pH} 7.8$, containing $1 \mathrm{mM}$ EDTA and centrifuged. Pellets were resuspended in the same buffer, frozen and stored at $-20^{\circ} \mathrm{C}$. Cell disruption was achieved by vigorously shaking the cellular suspension with $0.5 \mathrm{~mm}$ diameter glass beads. Cellular extracts were then obtained by centrifugation at $5000 \times g$ for $15 \mathrm{~min}$ at $4{ }^{\circ} \mathrm{C}$ and overnight dialysis $(14,000$ cut-off membrane) of the supernatant against buffer at $4{ }^{\circ} \mathrm{C}$. Preliminary experiments showed there was no loss of enzymatic activities by overnight storage at $4{ }^{\circ} \mathrm{C}$.

\subsection{Microscopic procedures}

An optical microscope (Zeiss, Axioskop) was used for all microscopic procedures. Cell viability was assessed by the methylene blue staining technique (Jones, 1987).

Genealogical profile of the samples was assessed by the method of the bud scars analysis (Soares and Mota, 1996). The cells were stained with calcofluor and observed using incident ultraviolet light with appropriate filters (excitation filter, $365 \mathrm{~nm}$, dichroic mirror, $395 \mathrm{~nm}$; barrier filter, $420 \mathrm{~nm}$ ). The number of bud scars per cell was scored for 300 cells per sample. The genealogical age of the cells was defined as the number of bud scars per cell. Cells were distributed in six classes: cells without bud scars, cells having one, two, three, four and more than four bud scars.

Cell-size distribution of the samples were automatically evaluated by an image processing system composed of an optical microscope coupled with a black and white camera (Sony CCD AVC D5CE) and linked to a microcomputer by a frame grabber (DT3155, Data Translation, Inc.). The images were acquired and processed using Image-Pro Plus 3.0/Windows, Media Cybernetics. Traditional tools generally used for image processing were employed (Coelho et al., in press) contours enhancement, background subtraction, feature extraction and objects separation. Objects were labelled permitting individual properties to be extracted. The projected area of each cell was used as cell-size parameter. The cells were observed immediately after sampling with $400 \times$ magnification and at least 300 cells per sample were used for the evaluation of cellsize distribution.

\section{Results}

An initial glucose feed below the critical glucose flux for this strain $\left(0.36 \mathrm{~g} \mathrm{~g}^{-1} \mathrm{~h}^{-1}\right)$ was used in all of the fed-batch experiments at different values of total pressure of air and pure oxygen. Thus, it was expected to observe pure oxidative metabolism in the absence of oxygen limitation. Aeration of the culture with air at atmospheric pressure $(0.1 \mathrm{MPa})$ was insufficient to prevent oxygen limitation (Fig. 1) and a significant switch of the metabolism to the fermentative pathway was observed, leading to a low global cell mass yield and a significant ethanol production (Table 1). The specific growth rate was quite lower than the pre-

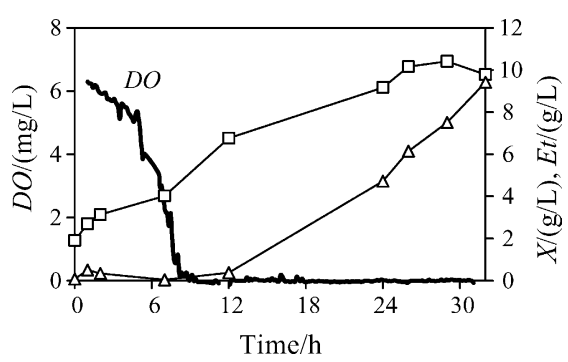

Fig. 1. Time course of dissolved oxygen concentration (DO), cell mass concentration $(X, \square)$ and ethanol concentration (Et, $\triangle)$ in the fed-batch experiment at $0.1 \mathrm{MPa}$. 
Table 1

Pressure effects on the global cell mass yield, $Y_{\mathrm{X} / \mathrm{S}}$, ethanol mass yield, $Y_{\mathrm{E} / \mathrm{S}}$, specific cell growth rate, $\mu$, and maximal cell concentration, $X_{\max }$ in the fed-batch cultivations of Saccharomyces cerevisiae with air and pure oxygen

\begin{tabular}{lrrrr}
\hline $\begin{array}{l}\text { Pressure } \\
(\mathrm{MPa})\end{array}$ & $Y_{\mathrm{X} / \mathrm{S}}(\%)$ & $Y_{\mathrm{E} / \mathrm{S}}(\%)$ & $\mu\left(\mathrm{h}^{-1}\right)^{\mathrm{a}}$ & \multicolumn{1}{c}{$\begin{array}{l}X_{\max } \\
\left(\mathrm{g} \mathrm{L}^{-1}\right)\end{array}$} \\
\hline 0.1 air & 24.3 & 25.4 & $0.04-0.08$ & 9.8 \\
0.6 air & 35.6 & 13.6 & $0.09-0.13$ & 15.4 \\
1.0 air & 37.1 & 13.2 & $0.08-0.12$ & 13.7 \\
1.5 air & 8.3 & 14.0 & $0.06-0$ & 1.7 \\
$0.13 \mathrm{O}_{2}$ & 35.9 & 14.4 & $0.08-0.11$ & 14.4 \\
$0.32 \mathrm{O}_{2}$ & 1.8 & 8.3 & $0.05-0$ & 4.6 \\
\hline
\end{tabular}

Data are means of two independent experiments.

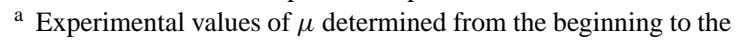
end of the fed-batch experiment.

dicted value $\left(0.1 \mathrm{~h}^{-1}\right)$ for the feeding profile used and the final cell mass concentration was 50\% lower than the maximum attainable value. Consequently, the experimentally determined specific glucose uptake rate $\left(0.3-0.4 \mathrm{~g} \mathrm{~g}^{-1} \mathrm{~h}^{-1}\right)$ deviated from the expected value and exceeded the critical value.

A 1.5-fold increase in the cell mass yield and a 1.8fold reduction of ethanol yield were obtained by increasing total air pressure to $0.6 \mathrm{MPa}$ or by the use of pure oxygen at $0.13 \mathrm{MPa}$. Under these conditions, the specific cell growth rate increased trough time closely to the expected value and the specific substrate uptake rates varied from $0.2 \mathrm{~g} \mathrm{~g}^{-1} \mathrm{~h}^{-1}$ to $0.3 \mathrm{~g} \mathrm{~g}^{-1} \mathrm{~h}^{-1}$. No significant further improvement of cell mass production was found for hyperbaric air at $1.0 \mathrm{MPa}$, which corresponds to $0.21 \mathrm{MPa}$ of oxygen partial pressure. Nevertheless, the results demonstrated that hyperbaric pressure of 1.0 MPa, does not inhibit cellular respiration of the yeast strain. Moreover, the absence of possible deleterious effects of pressure on the physiological state of the cells is also confirmed by the high numbers of the viable cells observed for the cultures under hyperbaric pressure of 1.0 MPa (Fig. 2).

Fed-batch experiments were performed at higher values of hyperbaric pressure of air (1.5 MPa) and pure oxygen $(0.32 \mathrm{MPa})$, but a drastic inhibition of cell growth was observed. Glucose uptake was also repressed since a glucose build-up in the medium occurred, contrarily to the other pressure conditions where glucose concentration was kept at a residual value smaller than $0.2 \mathrm{~g} \mathrm{~L}^{-1}$. Also, a large reduction in cell viability with the exposure time to increased

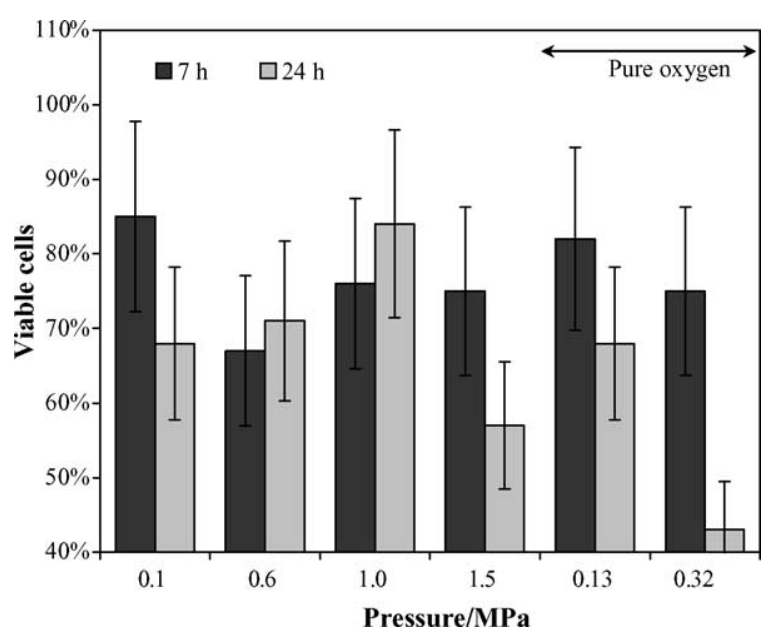

Fig. 2. Effect of air pressure (from 0.1 MPa to 1.5 MPa) and oxygen pressure (at $0.13 \mathrm{MPa}$ and $0.32 \mathrm{MPa}$ ) on cell viability assessed by the methylene blue staining method, in cell samples collected at $7 \mathrm{~h}$ and $24 \mathrm{~h}$ of fed-batch growth. Data are mean \pm confidence interval at $95 \%$ level.

oxygen and air pressure (Fig. 2) was obtained. Due to the experimental errors associated to the cell viability determination method no statically significant differences (at a 95\% confidence level) were found on the percentage of viable cells at $7 \mathrm{~h}$ exposure to the different atmospheres and the most significant change was obtained for the culture under $0.32 \mathrm{MPa}$ of oxygen for $24 \mathrm{~h}$.

The stronger effects of $0.32 \mathrm{MPa}$ of pure $\mathrm{O}_{2}$ pressure on cell activity and viability than the effects of $1.5 \mathrm{MPa}$ of air pressure indicates that is not the total pressure to a maximum of $1.5 \mathrm{MPa}$ that causes cell inhibition, but the toxicity of oxygen higher than $0.21 \mathrm{MPa}$.

Fig. 3 presents the data of the activities of the antioxidant enzymes, catalase and SOD, mithocondrial (MnSOD) and cytosolic (CuZnSOD), measured at the end of the cell cultivation under hyperbaric conditions.

Catalase and MnSOD were induced by hyperbaric air to a maximum of $1.0 \mathrm{MPa}$ and $0.13 \mathrm{MPa}$ of pure $\mathrm{O}_{2}$ pressure, but no statistically significant changes (at a $95 \%$ confidence level) were observed for CuZnSOD activity. The respiratory activity and cell growth rate also increased with pressure rise, which implies that mitochondrial activity also increased. Mitochondria are the major sources of ROS, which explains the MnSOD induction. When cell growth was retarded by pressure an induction of CuZnSOD was observed, in opposition 


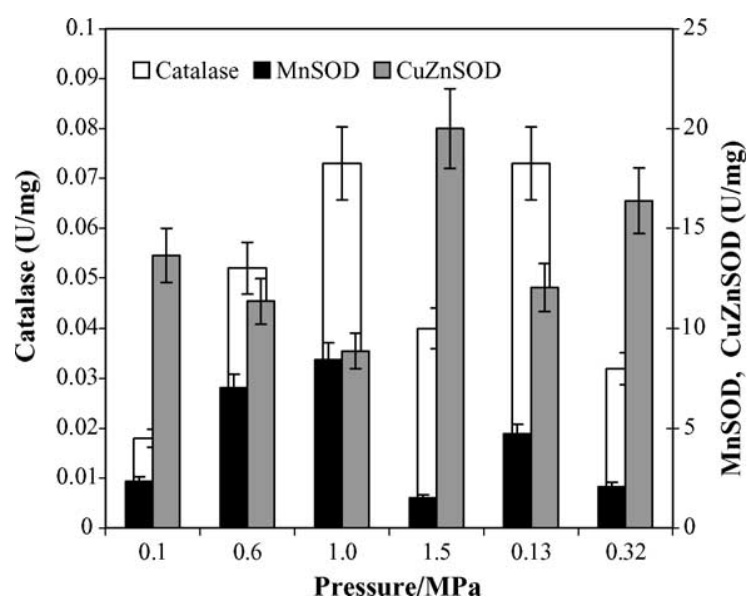

Fig. 3. Effect of air pressure (from 0.1 MPa to 1.5 MPa) and oxygen pressure (at $0.13 \mathrm{MPa}$ and $0.32 \mathrm{MPa}$ ) on catalase and superoxide dismutase (mithocondrial and cytosolic isoformes) activities, in the final fed-batch cell cultures ( $24 \mathrm{~h}$ of growth). Data are mean \pm confidence interval at $95 \%$ level.

to the MnSOD and catalase. The response of CuZnSOD also indicates that ROS could be generated in the cytosol, due to oxygen over provision by other mechanisms not associated to respiration.

The effects of hyperbaric pressure on yeast reproduction was analysed by genealogical age determination. The genealogical age profiles of the cultures samples collected at $24 \mathrm{~h}$ of growth under hyperbaric pressure are presented in Fig. 4. No differences were found between the genealogical age of cell populations under environments of air at $0.1 \mathrm{MPa}, 0.6 \mathrm{MPa}, 1.0 \mathrm{MPa}$ and pure oxygen at $0.13 \mathrm{MPa}$. The majority of the cells are young with no bud scars (daughter cells), or with only one bud scar. This behaviour is in accordance with the cell growth rate at a near constant value (Soares and Mota, 1996). Changes in the genealogical age profile were obtained for the final cultures exposed to $1.5 \mathrm{MPa}$ of air pressure and $0.32 \mathrm{MPa}$ of $\mathrm{O}_{2}$ pressure. The differences in the genealogical age distribution of these cell populations and the cell populations grown at lower values of pressure were statically significant $(P<0.01$, $\chi^{2}$ test). An increase in the fraction of cells with more than four bud scars was observed, which indicates that the old cells are more resistant to pressure than young cells. Once again no synergic effects of total pressure and oxygen concentration were recorded for increased pressure on genealogical age distribution. Thus, oxy-
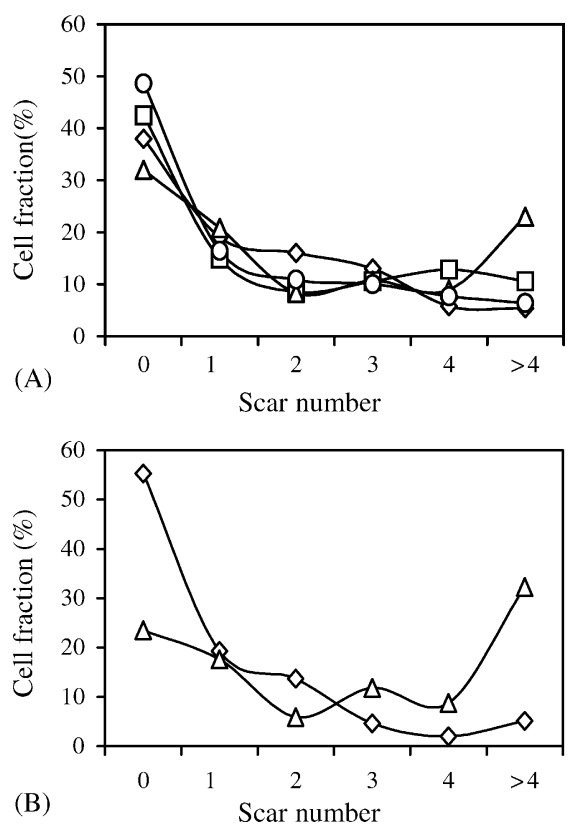

Fig. 4. Effect of air pressure $(\mathrm{A})((\diamond) 0.1 \mathrm{MPa},(\bigcirc) 0.6 \mathrm{MPa},(\square)$ $1.0 \mathrm{MPa}$ and $(\Delta) 1.5 \mathrm{MPa}$ ) and oxygen pressure $(\mathrm{B})(\diamond) 0.13 \mathrm{MPa}$ and $(\Delta) 0.32 \mathrm{MPa}$ ) on the genealogical age distribution of the final fed-batch cell cultures ( $24 \mathrm{~h}$ of growth).

gen toxicity is confirmed as the true cause of cell inhibition by hyperbaric air.

The cell-size distribution of yeast cells exposed to hyperbaric pressures of air was analysed by a computeraided image analysis technique (Coelho et al., in press). Typical Gaussian distributions were obtained for all the cell population analysed. Fig. 5 illustrates two examples and Table 2 presents the Gaussian parameters of the final cell cultures under hyperbaric air (Fig. 5).

While the decrease in the mean cell area obtained for cells under $0.6 \mathrm{MPa}$ and $1.0 \mathrm{MPa}$ of air pressure can be correlated with the faster cell growth, the decrease of the cell area obtained at $1.5 \mathrm{MPa}$ of air pressure means

Table 2

Air pressure effects on the mean projected area of the cells at $24 \mathrm{~h}$ of growth

\begin{tabular}{ll}
\hline Air pressure $(\mathrm{MPa})$ & Projected area $^{\mathrm{a}}$ \\
\hline 0.1 & $35 \pm 2$ \\
0.6 & $27 \pm 1$ \\
1.0 & $25 \pm 1$ \\
1.5 & $20 \pm 1$ \\
\hline
\end{tabular}

${ }^{\text {a }}$ Mean \pm standard deviation $(n>300)$. 

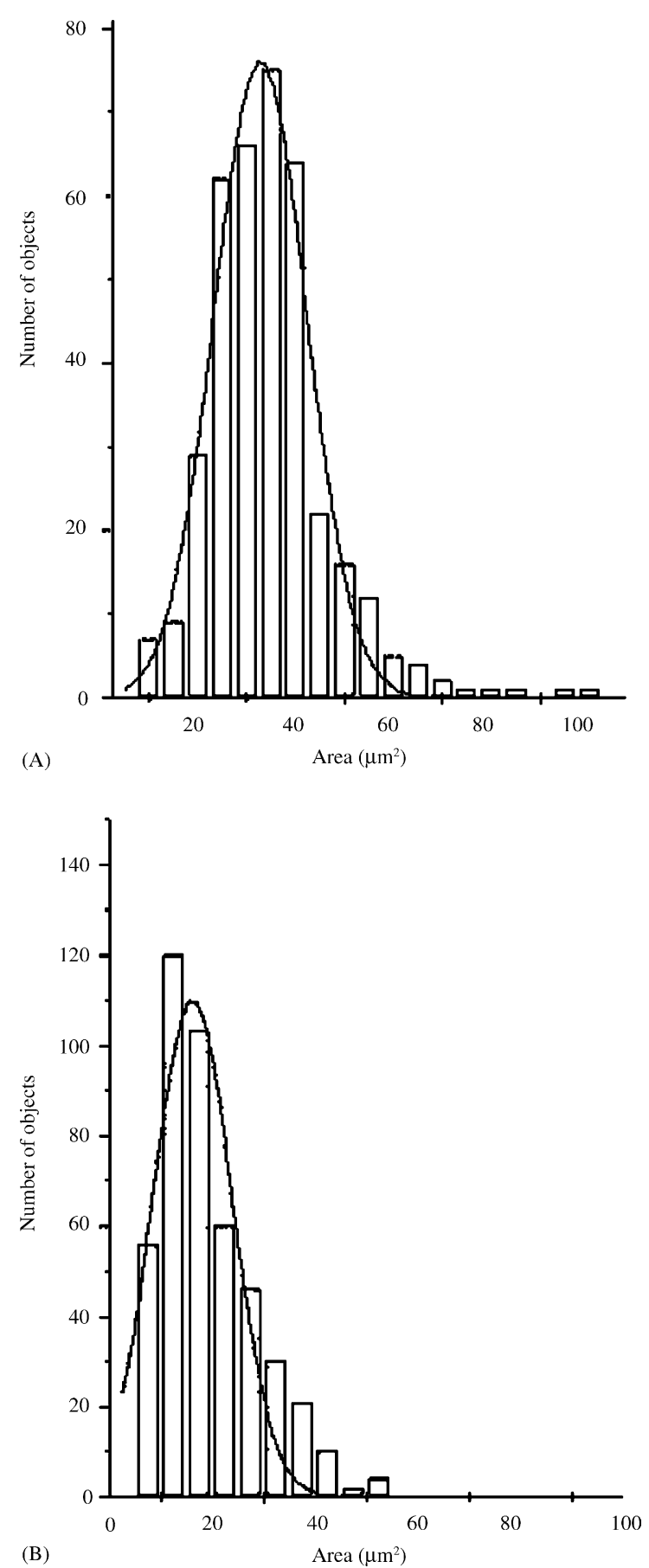

Fig. 5. Histograms and Gaussian fit for the projected area of the final cells exposed to $0.1 \mathrm{MPa}(\mathrm{A})$ and $1.5 \mathrm{MPa}(\mathrm{B})$ of air pressure. a cell compression because cells were not growing and there was an increase on the percentage of older cells that under normal conditions are bigger in size.

\section{Discussion}

Yeasts are subjected to many types of stress throughout cultivation processes (e.g. pressure and oxidative stress). Knowledge on the impact of these stress factors and their lethal limits is crucial to establish and control operating conditions.

In aerobic yeast cultivation, total pressure is an important stress factor, largely because it changes the partial pressure of dissolved gases, and in particular dissolved oxygen concentration can cause oxidative stress to the cells.

In this work, a limit for the oxygen partial pressure of $0.21 \mathrm{MPa}$ (i.e. 1.0 MPa of air) was found, above which cell inhibition was observed. Lower limits for the oxygen partial pressure at which cell growth was inhibited, has been report (Lee and Hassan, 1987; Abel et al., 1994), although other methods were used for yeast cultivation.

For the fed-batch operation used in this work, it was possible to improve cell mass production by a 6 - and 10-fold increase of air pressure, but there was still some ethanol production. Previous work showed that at identical experimental operation conditions, theoretical cell mass yield could be attained if air pressure is gradually increased (up to 1.0 MPa) through operation time (Belo et al., 2003).

The oxygen toxicity caused respiratory and fermentative activity inhibition, as well as cell viability reduction. Oxidative stress emerges as a consequence of the limits of the anti-oxidant enzymes induction. Different effects could also explain enzyme behaviour. SOD activity is also affected by other factors, such as growth rate and phase. Westerbeek-Marres et al. (1988) reported a reduction of the MnSOD activity of yeast cells and an increase of CuZnSOD activity in the transition from the exponential to stationary phase of cell growth, which is in accordance with the results reported herein. On the other hand, according to Westerbeek-Marres et al. (1988) CuZnSOD is induced by catabolic repression, thus the increase in the activity of this enzyme could also result from glucose accumulation in the culture medium, since substrate uptake was inhibited by 
pressure. The differences in the response to hyperbaric pressure of the anti-oxidant enzymes may explain the limits to cell protection against oxidative stress, with the consequent oxygen toxicity observed above certain limits of pressure. In particular, the imbalance of the catalase and cytosolic SOD activities can lead to insufficient scavenging of ROS inside cell. However, other peroxidases could demonstrate different behaviour to catalase and contribute to ROS elimination (Izawa et al., 1995). Moreover, other authors have reported catalase repression by pure oxygen at $0.1 \mathrm{MPa}$ (Lee and Hassan, 1987).

Oxidative stress was also responsible for cell aging and cell size decrease. The genealogical age profile determination in addition to cell-size determination was a useful tool to conclude that oxidative stress caused cell compression. When pressure did not affect cell growth, distributions of the genealogical age of cells were similar to the ones reported to yeast cells at the exponential phase of growth (Soares and Mota, 1996).

Besides cell age, the size and shape of yeast cells depend on several factors, such as phase of growth, medium composition, operating conditions, among others. Hydrostatic pressure above values of $10^{2} \mathrm{MPa}$ of magnitude is a well-known environmental factor that alters yeast morphology (Shimada et al., 1993). Perrier-Cornet et al. (1995) reported a compression of yeast cells by $250 \mathrm{MPa}$ of hydrostatic pressure. It was claimed that the reason for this compression was the cell mass transfer from the inside of the cell to the exterior medium, due to the change of membrane properties by pressure. This explanation applies to the results reported here since it is well know that oxidative stress can damage cells membranes by lipid peroxidation, leading to changes in membrane permeability and fluidity. This effect is supported by the decrease in viable cells in final cultures at $1.5 \mathrm{MPa}$ air and $0.32 \mathrm{MPa}$ oxygen. Moreover, the method used for the cell viability determination, the methylene blue staining method, depends on the membrane permeability, giving low viabilities as the membrane permeability increases. The damage of cell membrane could also be attributed to the abrupt decompression of dissolved gases during sample collection. However, this phenomenon does not affect membrane permeability of $S$. cerevisiae, for gas pressures as high as $5 \mathrm{MPa}$ (Bavouzet et al., 1994).

Nevertheless, little information is still available about the effects of pressure, in a moderated range of values, on the shape and size of yeast cells. The work reported here may contribute to the improvement of that knowledge and demonstrated the usefulness of hyperbaric bioreactors to perform oxidative stress studies.

\section{References}

Abel, C., Hübner, U., Schügerl, K., 1994. Transient behaviour of baker's yeast during enforced periodical variation of dissolved oxygen concentration. J. Biotecnhol. 32, 45-57.

Bavouzet, J.M., Lafforgue-Delorme, C., Fonade, C., Goma, G., 1994. A novel device for the assessment of normal stresses time variations effects on suspended cell: design and performances. Biotechnol. Tech. 8, 663-670.

Beers, R.F., Sizer, I.W., 1952. A spectrophotometric method for measuring breakdown of hydrogen peroxide by catalase. J. Biol. Chem. 195, 276-287.

Belo, I., Mota, M., 1998. Batch and fed-batch cultures of E. coli TB1 at different oxygen transfer rates. Effect of stirring and oxygen partial pressures on cell growth and cytochrome $b_{5}$ production. Bioprocess Eng. 18, 451-455.

Belo, I., Pinheiro, R., Mota, M., 2003. Fed-batch cultivation of Saccharomyces cerevisiae in a hyperbaric bioreactor. Biotechnol. Prog. 19, 665-671.

Bradford, M.M., 1976. A rapid and sensitive method for the quantification of microgram quantities of protein using the principle of protein-dye binding. Anal. Biochem. 72, 248-255.

Coelho, M.A.Z., Belo, I., Pinheiro, R., Amaral, A.L., Mota, M., Coutinho, J.A.P., Ferreira, E.C., in press. Effect of hyperbaric stress on yeast morphology: study by automated image analysis. Appl. Microbiol. Biotechnol.

Gervais, P., Marechal, P.A., Molin, P., 1992. Effects of the kinectics of osmotic pressure variation on yeasts viability. Biotechnol. Bioeng. 40, 1435-1439.

Izawa, S., Inoue, Y., Kimura, A., 1995. Oxidative response in yeast: effect of glutathione on adaptation to hydrogen peroxide stress in Saccharomyces cerevisiae. FEBS Lett. 368, 73-76.

Jones, R.-P., 1987. Measures of yeast death and deactivation and their meaning: Part I. Process Biochem., 118-128.

Koo, J.H., Kim, S.Y., Park, Y.C., Han, N.S., Seo, J.H., 1998. Invertase production by fed-batch fermentations of recombinant Saccharomyces cerevisiae. J. Microbiol. Biotechnol. 8, 203-207.

Lee, F., Hassan, H., 1987. Biosynthesis of superoxide dismutase and catalase in chemostat cultures of Saccharomyces cerevisiae. Appl. Microbiol. Biotechnol. 26, 531-540.

McCord, J.M., Fridovich, I., 1969. Superoxide dismutase: an enzymatic function for erythrocuprein (hemocuprein). J. Biol. Chem. 244, 6049-6050.

Miller, G.L., 1959. Use of dinitrosalicylic acid reagent for determination of reducing sugar. Anal. Chem. 31, 426-428.

Moradas-Ferreira, P., Costa, V., Piper, P., Mager, W., 1996. The molecular defences against reactive oxygen species in yeast. Mol. Microbiol. 19, 651-658. 
Perrier-Cornet, J.-M., Maréchal, P.-A., Gervais, P., 1995. A new design intended to relate high pressure treatment to yeast cell mass transfer. J. Biotechnol. 41, 49-58.

Pinheiro, R., Belo, I., Mota, M., 2000. Air pressure effects on biomass yield of two different Kluyveromyces strains. Enzyme Microbiol. Technol. 26, 756-762.

Raynal, L., Barnwell, P., Gervais, P., 1994. The use of epiflourescence to determine the viability of Saccharomyces cerevisiae subjected to osmotic shifts. J. Biotechnol. 36, 121-127.

Santoro, N., Thiele, D.J., 1997. Oxidative stress responses in the yeast Saccharomyces cerevisiae. In: Hohmanne, S., Mager, W.H. (Eds.), Yeast Stress Responses. Springer-Verlag, Heidelberg, Germany, pp. 172-211.

Shimada, S., Andou, M., Naito, N., Yamada, N., Osumi, M., Hayashi, R., 1993. Effects of hydrostatic pressure on the ultrastructure and leakage of internal substances in the Saccharomyces cerevisiae. Appl. Microbiol. Biotechnol. 40, 123-131.

Soares, E.V., Mota, M., 1996. Flocculation onset, growth phase, and genealogical age in Saccharomyces cerevisiae. Can. J. Microbiol. $42,1-9$.
Van Hoek, P., Hulster, E., van Dijken, J.P., Pronk, J., 2000. Fermentative capacity in high-cell-density cultures of Baker's yeast. Biotechnol. Bioeng. 68, 517-523.

Wendlandt, K.-D., Jechorek, M., Brühl, E., 1993. The influence of pressure on the growth of methanotrophic bacteria. Acta Biotechnol. 13, 11-115.

Westerbeek-Marres, C.A.M., Moore, M.M., Autor, A.P., 1988. Regulation of manganese superoxide dismutase in Saccharomyces cerevisiae: The role of respiratory chain activity. Eur. J. Biochem. 174, 611-620.

Yang, J.D., Wang, N.S., 1992. Oxygen mass transfer enhancement via fermentor headspace pressurization. Biotechnol. Prog. 8, 244-251.

Yee, L., Blanch, H.W., 1992. Recombinant protein expression in high cell density fed-batch cultures of Escherichia coli. Biotechnology $10,1550-1556$.

Zalewski, K., Buchholz, R., 1996. Morphological analysis of yeast cells using an automated image processing system. J. Biotechnol. $48,43-49$. 